
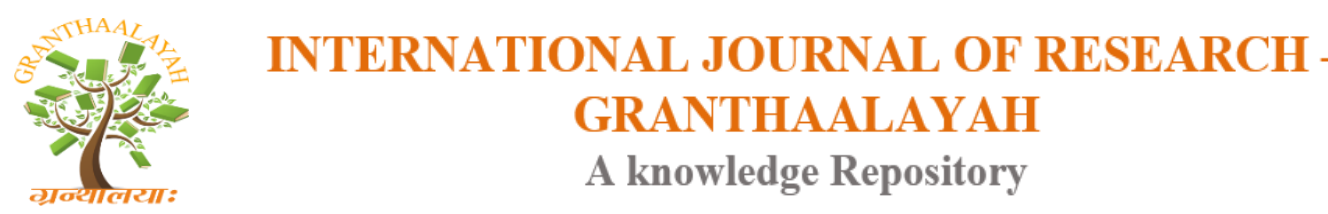

Science

\title{
ESTIMATION OF SURFACE RUNOFF FOR AL-MAHALAH CATCHMENT'S USING SCS CURVE NUMBER METHOD AND GEOGRAPHIC INFORMATION SYSTEM TOOLS
}

\author{
Safa Mazahreh *1, Lubna Al Mahasneh ${ }^{1}$, Aktar Ali ${ }^{2}$ \\ ${ }^{* 1}$ Environment and Climate Change Research directorate, NARC, Jordan \\ ${ }^{*}$ ICARDA
}

\begin{abstract}
Natural resources and their sustainable management are key issues for the future development of national agricultural Strategy in Jordan. Similarly, vegetative cover, particularly rangelands, and its sustainable management are key concern in combating land degradation.

The study area is located in the northern eastern area of Jordan and classified as Marginal area between with average annual rainfall less than $200 \mathrm{~mm}$. It suffers from land degradation due to overgrazing and mismanagement of vegetation cover, which has a substantial impact on the production system. Although it has a potential for water management.

The main objective of this study is to estimate the runoff for Al-Mahalah watershed (using SCS Curve Number method) to construct an earth dam at suitable location in the watershed in order to harvest water for the benefit of local community and conserve soil.

Data integration, analysis and processing for available and collected data were carried out in GIS environment. Runoff amounts were estimated at the watershed's outlet and the proposed location of an earth dam.

The total amounts of runoff that could be derived from Al-Mahalah catchment's area at the catchment's outlet and an earth dam were estimated to be approximately 40000, $15000 \mathrm{~m} 3$, respectively.
\end{abstract}

Keywords: Geographic Information Systems; SCS Curve Number Method; Runoff.

Cite This Article: Safa Mazahreh, Lubna Al Mahasneh, and Aktar Ali. (2018). "ESTIMATION OF SURFACE RUNOFF FOR AL-MAHALAH CATCHMENT'S USING SCS CURVE NUMBER METHOD AND GEOGRAPHIC INFORMATION SYSTEM TOOL." International Journal of Research - Granthaalayah, 6(6), 408-413.

\section{Introduction}

Water resources and their sustainable management are key issues for the future development in the region Strategy. Similarly, vegetative cover, particularly rangelands, and its sustainable management are key concern in combating land degradation. 
Faa' study area in Jordan is a Marginal area between agricultural land and desert area. It suffers from land degradation due to overgrazing and mismanagement for vegetation cover, which has a substantial impact on the production system. Also it has a potential for water management and conservation due to moderate rainfall and runoff potential.

Data integration, analysis and processing for available and collected data were carried out in GIS environment. Runoff amounts were estimated using SCS Curve Number method. The runoff amounts were calculated at each sub watershed. Also at the outlet of watershed and at the proposed location of an earth dam.

\section{Objective}

The main objective of this study is to estimate the runoff for Al-Mahalah watershed (using SCS Curve Number method) to construct an earth dam at suitable locations in the watershed in order to harvest water and conserve soil using runoff water.

\section{Methodology}

Relying on the soil survey report ${ }^{1}$ at scale 1:10000, the paper maps were transformed into digital maps using GIS. Thematic maps were extracted from the attribute table attached with the soil units of the catchment's area using GIS functions.

\section{Study Area Description}

The study area, Faa' watershed, which lies within Mafraq area (Figure 1) is situated between 411697 to $414894 \mathrm{E}$ and 585410 to $589068 \mathrm{~N}$ (JTM) with an elevation ranging from 650-800 m above MSL (Mean Sea Level) and extends over a total area of 4456 dunum.

\section{Site-specific land degradation problems are:}

1) Wind erosion

2) Inefficient use of available water and water-induced erosion

3) Overgrazing and poor vegetative cover

4) Shrub uprooting for fuel

5) Weak soil structure

6) All private lands

7) Aridification

8) Mono cropping (barley cultivation)

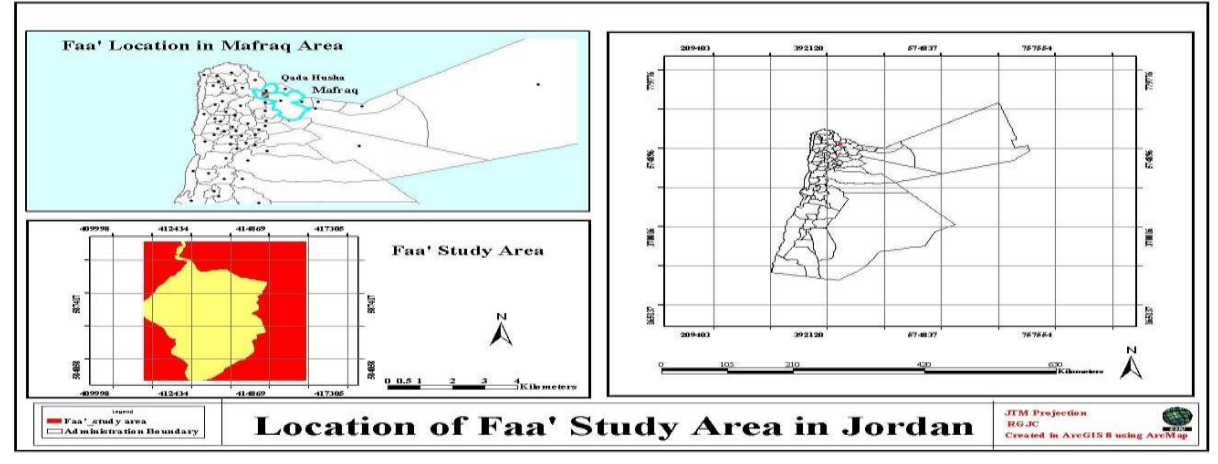

Figure 1: Location of Faa; study area in Jordan 
The watershed receives an average annual rainfall (1991-2003) of $148 \mathrm{~mm}$ where most of the rainfall is received during winter (October and February). The minimum and maximum annual temperature varies in the range of $9.6 \mathrm{C}$ to $24 \mathrm{C}$. The mean relative humidity is $62 \%$. The overall climate of the area can be classified as arid to semi-arid. The soil is mainly silty clay to silty clay loam type occupying the maximum area with a land slope varying from 5 to $49 \%$ where slope decreases at the North. The soil depth varies between shallow $(<30 \mathrm{~cm})$ and deep $(>100 \mathrm{~cm})$. The Exisiting landuse were categorized into (Annual field crops $(\mathrm{A} / \mathrm{C})$ which represent $41.5 \%$ of catchments area, range land (R/L) with $43.4 \%$, trees $(\mathrm{T} / \mathrm{C})$ with $5 \%$, and the other mixed by the following: trees with urban $(\mathrm{T} / \mathrm{C}+\mathrm{U})$ which occupy $5.6 \%$, trees with annual field crops $(\mathrm{T} / \mathrm{C}+\mathrm{A} / \mathrm{C})$ at $3.7 \%$ and finally trees with Range land $(\mathrm{T} / \mathrm{C}+\mathrm{R} / \mathrm{L})$ at $0.6 \%$ from total area. In addition Roman ancient locates in the study area with small area.

\section{Data Collection}

Two types of information were required to carry out the water assessment study:

\section{1) GIS Layers}

Topographic maps which describe elevation contour lines, stream network were used to delineate the sub watersheds of Faa' study area. In addition, Slope, Soil mapping units, Soil texture, Soil depth, Land cover and Existing Land Use maps were the basic GIS layers to carry out the study.

\section{2) Rainfall Data}

Data of Khanasri rainfall station were the basic information for the rainfall analysis. Data covers 13 years (1991-2003) daily rainfall.

\section{Runoff Estimation}

\section{1) Approach}

Soil Conservation Service (SCS, 1972) ${ }^{2}$ was applied in this study for the estimation of runoff from Faa' watershed. This method involves various types of information related to Hydrologic soil Group, vegetation and antecedent moisture condition of the watershed.

The Curve Number method (SCS, 1972), also known as the hydrologic soil cover complex method, is a versatile and widely used procedure for runoff estimation. This method includes several important properties of the watershed namely infiltration rate, land use and antecedent soil water conditions which are taken into consideration.

The main advantages of this method are: simple, predictable conceptual based method for estimation direct runoff depth from rainfall depth, reasonably well documented and widely accepted method for use in the United States and other countries. On the other hand, the main limitation of this method is that the $\mathrm{CN}$ describes average conditions that are useful in design; however, it reduces the modeling accuracy for historical events. 
The SCS method with initial abstraction consideration is given below: The curve number method assumes that:

$$
\begin{aligned}
& \mathrm{S}=\frac{25400-254 \ldots \ldots \ldots \ldots \ldots \ldots \ldots \ldots \ldots \ldots \ldots \ldots \ldots \ldots}{\mathrm{CN}} \\
& \mathrm{Q}=(\mathrm{P}-0.2 \mathrm{~S})^{2} \ldots \ldots \ldots \ldots \ldots \ldots \ldots \ldots \ldots \ldots \\
& (\overline{\mathrm{P}+0.8 \mathrm{~S})} \\
& \mathrm{CCN}=\frac{\sum\left(\mathrm{CNi} \times \mathrm{A}_{\mathrm{i}}\right)}{\mathrm{A}}
\end{aligned}
$$

Where,

$\mathrm{Q}=$ Runoff depth, mm

$\mathrm{P}=$ Rainfall, $\mathrm{mm}$

$\mathrm{S}=$ Maximum recharge capacity of watershed after 5 days rainfall antecedent

$\mathrm{I}_{\mathrm{a}}=0.2 \mathrm{~S}$ (Initial abstraction of rainfall by soil and vegetation, $\mathrm{mm}$ )

$\mathrm{CN}=$ Curve Number, $\mathrm{CN}$ is found out from the table.

Where

$\mathrm{CCN}=$ Composite Curve Number.

$\mathrm{CN}_{\mathrm{i}}=$ curve number from 1 to any no. $\mathrm{n}$.

$\mathrm{A}_{\mathrm{i}}=$ area with curve number $\mathrm{CN}_{\mathrm{I}}$

$\mathrm{A}=$ the total area of the watershed.

\section{2) Data Required}

- Soil texture to manipulate the infiltration rate2 of the soil.

- Area of each subwatershed.

- Existing land use for the subwatersheds where annual crops, trees, range land and some urban areas characterize the watershed.

- Rainfall amounts that causes runoff.

\section{3) Data Analysis and Processing}

For each subwatershed, area, existing land use, soil texture were identified.

Determination of infiltration rate was based on soil texture class ${ }^{2}$ in each and accordingly derivation of HSG's. The dominant soil texture was Silty clay loam to Silty loam. Consequently, in our study area HSG was found class "C". As a result, hydrological condition was found poor according to IR and soil texture.

Estimation of $\mathrm{CN}$ was derived according to land use, HSG, and hydrological condition. The composite $\mathrm{CN}$ was determined as weighted average for each subwatershed and their range was found between (84-89), figure 2 .

Extracting the runoff depth in inches from an international curve ${ }^{3}$ or/ and from the equation (2) using the two basic factors: $\mathrm{CN}$ and rainfall in inches. 




\section{4) Rainfall Analysis}

Thirteen daily rainfall data were available from Khanasri station (1991-2003). The average annual rainfall was computed for the thirteen years as $148 \mathrm{~mm}$ and it was found that year 2000 was the representative year to carry out the analysis.

\section{5) Results}

The runoff amounts were estimated according to composite $\mathrm{CN}$ and rainfall that caused runoff from an international curve used for this purpose. The runoff in cubic meter was estimated for each sub-basin according to its area. The total amounts of runoff that could be derived from Al-Mahalah catchment's area at the catchment's outlet and at the expected location of an earth dam were estimated to be approximately 40000 (figure3), 15000 (figure4) cubic meters, respectively.

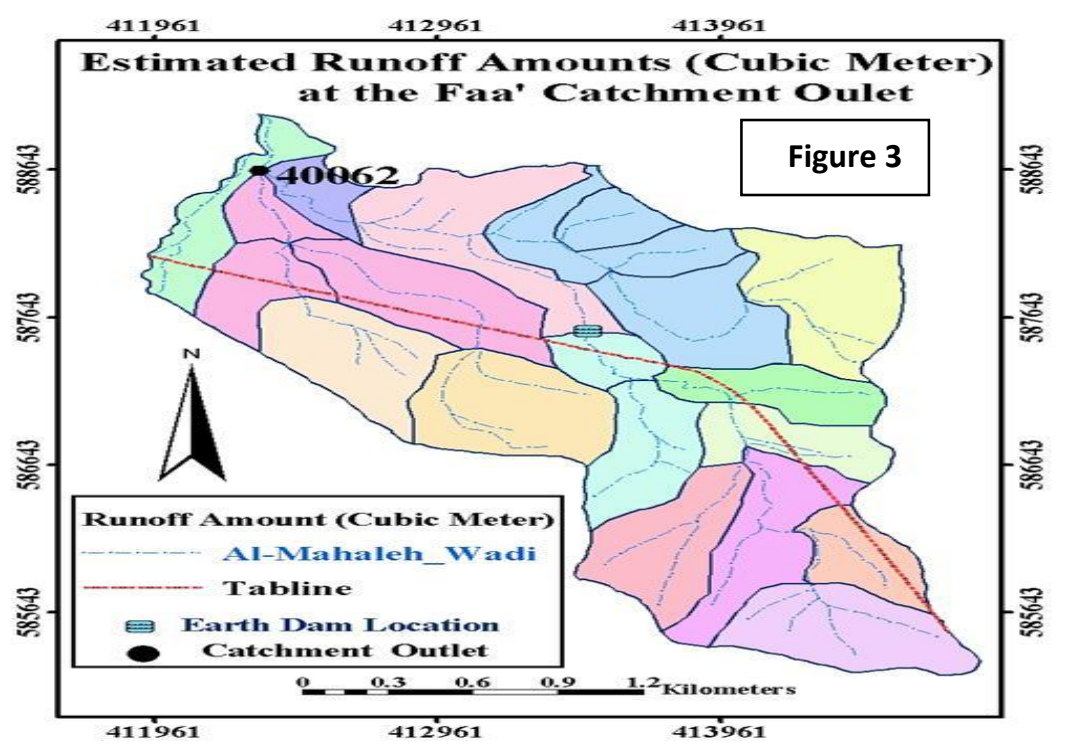




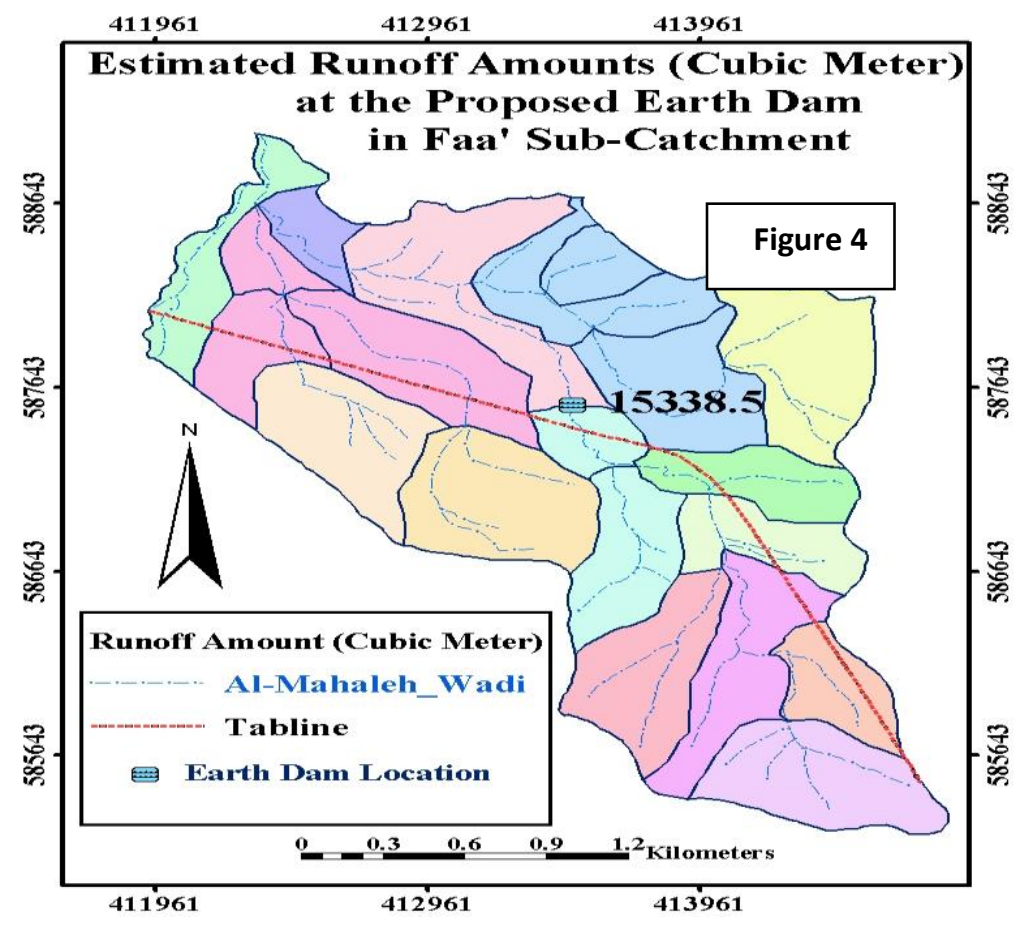

\section{References}

[1] Report of "Soil survey and landuse in Faa' study area", eng. Mahmoud Hamasha, 2004.

[2] Wanielesta. M., Kerstan.R, and Eaglin.R, "Hydrology: Water Quantity and QualityControl".2nd edition, University of Florida.

[3] International curve adapted from USDA" Urban Hydrology for Small watershed"

*Corresponding author.

E-mail address: s_mazahreh@yahoo.com 